\title{
TRANSPARENT CONDUCTING ZnO:In THIN FILMS PREPARED BY MAGNETRON DC SPUTTERING METHOD
}

\author{
Ho Van Binh, Le Vu Tuan Hung, Le Queo, Pham Thanh Tuan, \\ Duong Ai Phuong, Le Van Hieu \\ University of Science, VNU-HCM \\ (Manuscript Received on November $29^{\text {th }}, 2010$, Manuscript Revised September $10^{\text {th }}, 2011$ )
}

ABSTRACT: ZnO:In thin films was deposited on glass substrate by magnetron DC sputtering method from ceramic target. The $\mathrm{ZnO}$ :In ceramic targets have concentrations of $\mathrm{In}_{2} \mathrm{O}_{3}$ varying between 1 and $4 w t \%$. The ZnO:In film has the resistivity with value of $1.79 \times 10^{-3} \Omega \mathrm{cm}$, at a layer thickness of about $1 \mu \mathrm{m}$, corresponding with $\mathrm{ZnO}$ :In target $\left(2 \%\right.$ wt $\left.\operatorname{In}_{2} \mathrm{O}_{3}\right)$, at the substrate temperature of about 240${ }^{0} \mathrm{C}$. All ZnO:In thin films have the transparence above $85 \%$ in the visible spectra.

Keywords: Magnetron DC sputtering, ZnO:In, Transparent Conducting Oxide (TCO).

\section{INTRODUCTION}

Transparent and conducting oxide (TCO) thin films with unique characteristics of low resistivity and high transparency over the visible wavelength region have numerous applications in optoelectronic devices including thin film solar cell, organic light emitting devices (OLED), and other flat panel displays. One of the common TCO films is ITO, it is used as anodes of several devices. However, indium is a rare metal in nature and the cost of experiment is increasing drastically. Recently, $\mathrm{Al}$, Ga or In doped zinc oxide films have been considered as possible alternatives to ITO films because $\mathrm{ZnO}$ thin films are less expensive than the ITO films. ZnO thin films were deposited by several techniques such as radio frequency (RF) sputtering process, pulsed laser deposition (PLD), sol-gel method, and chemical vapor synthesis $(\mathrm{CVS})$...In this research, indium doped zinc oxide (IZO) thin films were prepared by magnetron DC sputtering method on glass substrates. the structural, optical, and electronic properties of the IZO films have been investigated with some different parameters depositing films such as the concentrations of indium and substrate temperature.

\section{EXPERIMENT}

IZO films were deposited on glass substrate by magnetron DC sputtering process. The $\mathrm{ZnO}$ :In ceramic targets were prepared by sintering the mixing $99 \% \mathrm{ZnO}$ and $99.5 \%$ $\mathrm{In}_{2} \mathrm{O}_{3}$ powders with the indium concentration changed from 1 to $4 \mathrm{wt} \%$. The sputtering chamber was pumped down to $1 \times 10^{-4}$ Torr by oiled diffusive pump. The substrate to target distance, sputtering time, working pressure, and sputtering currency, sputtering potential were kept at $3 \times 3 \mathrm{~cm}, 35 \mathrm{~min}, 3 \mathrm{~m}$ Torr, $0.2 \mathrm{~A}$, 
$600 \mathrm{~V}$, respectively. The substrate temperature of IZO films was changed from $50{ }^{\circ} \mathrm{C}$ to 300 ${ }^{0} \mathrm{C}$.

The crystal structure, electrical and optical properties were investigated by X-ray diffraction (XRD) measurement, four probe method, UV-vis spectrometer.

\section{RESULTS AND DISCUSSION}

\subsection{Structural and electrical properties}

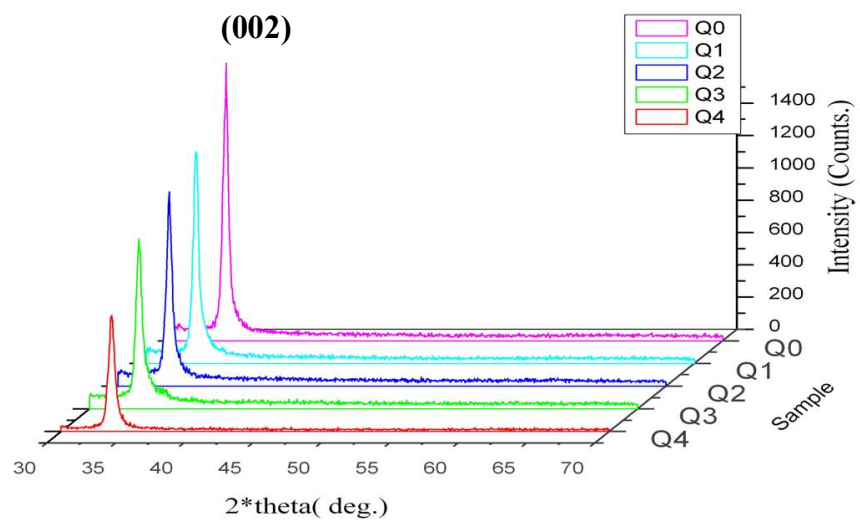

Fig.1. XRD patterns of IZO films with differences in concentrations of indium

Table 1. Researching the resistivity of IZO films deposited with different indium concentrations in IZO ceramic targets

\begin{tabular}{|l|l|l|l|l|l|}
\hline \%wt $\mathrm{In}_{2} \mathrm{O}_{3}$ & $0 \%$ & $1 \%$ & $\mathbf{2 \%}$ & $\mathbf{3 \%}$ & $4 \%$ \\
\hline Thickness $(\mathrm{nm})$ & 1080 & 880 & $\mathbf{9 6 0}$ & $\mathbf{9 5 0}$ & 950 \\
\hline Resistant sheet $\Omega / \square$ & 31.3 & 34.1 & $\mathbf{2 2 . 1}$ & $\mathbf{2 2 . 8 5}$ & 35.16 \\
\hline Resistivity $\boldsymbol{\rho}\left(\mathrm{x} 10^{-3}\right) \Omega \mathrm{cm}$ & 3.38 & 3.00 & $\mathbf{2 . 1 2}$ & $\mathbf{2 . 1 7}$ & 3.34 \\
\hline
\end{tabular}

Fig. 1 shows XRD spectra of IZO films correspond with the indium concentration changed between 1 and $4 \mathrm{wt} \%$. As concentration of indium increases, the crystal structure of IZO films decrease, corresponding with the decrease of the (002) intensity peak. This could be explained that indium inserted in IZO films when the indium concentration increased, and the Indium itself had induced the crystal structure of IZO films. 


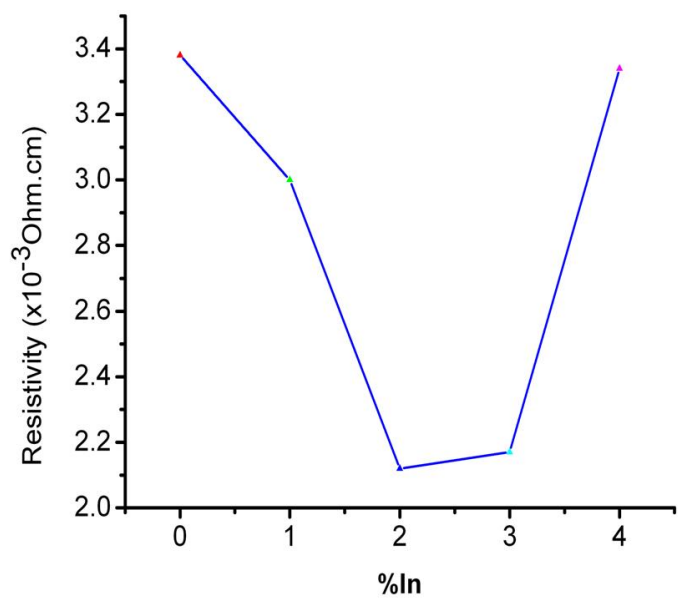

$\% \mathrm{In}_{2} \mathrm{O}_{3}$

Fig. 2. The resistivity of IZO films deposited with different indium concentrations in IZO ceramic targets

Tab. 1 and Fig. 2 show that the resistivity of IZO films decreases when the indium concentration in target increases from 1 to $2-3$ $\mathrm{wt} \%$, but if the In concentration continues increasing, the resistivity of IZO films also increase. This could be explained that firstly the increasing In concentration makes the carrier concentration of IZO films increase, result as the resistivity of IZO films decrease,
On the contrary, when the In concentration exceeds the threshold value (about 2-3 wt\%) the mobility of carrier will be decreased due to occurring in grain boundary scattering and leading to the resistivity of films increase.

Therefore, the best In concentration is about $2-3 \mathrm{wt} \%$. We can compare this results with that of scientists (J.Wienke và A.S Booij)[1] and shows that it is well appropriate.

Table 2: The resistivity of IZO films deposited with different substrate temperatures.

\begin{tabular}{|c|l|l|l|l|l|l|l|l|l|}
\hline $\mathrm{T}_{\mathrm{S}}\left({ }^{0} \mathrm{C}\right)$ & 100 & 140 & 180 & 200 & $\mathbf{2 2 0}$ & $\mathbf{2 4 0}$ & 260 & 280 & 300 \\
\hline Thickness(nm) & 920 & 1010 & 960 & 970 & $\mathbf{1 0 2 0}$ & $\mathbf{9 1 0}$ & 980 & 1050 & 950 \\
\hline $\begin{array}{c}\text { Resistant sheet } \\
\Omega / \square\end{array}$ & 150 & 33.56 & 22.10 & 21.5 & $\mathbf{1 8 . 0 4}$ & $\mathbf{1 9 . 7}$ & 19.5 & 19.4 & 23 \\
\hline $\begin{array}{c}\text { Resistivity }(\rho) \\
\left(\mathrm{x} 10^{-3}\right) \Omega \mathrm{cm}\end{array}$ & 138 & 3.39 & 2.12 & 2.09 & $\mathbf{1 . 8 4}$ & $\mathbf{1 . 7 9}$ & 1.91 & 2.04 & 2.19 \\
\hline
\end{tabular}


Tab.2 shows that as the substrate temperature increases, the resistivity of films decrease, because substrate temperature plays as catalysis to aid In inserting in IZO films more easily, and leading to the increase in carrier concentration. Moreover, temperature also helps films to improve their crystal structures, and the incorporation between substrate and films, and the incorporation between films and In donor. From that the resistivity of films decreases.[2,3]

\subsection{Optical properties}

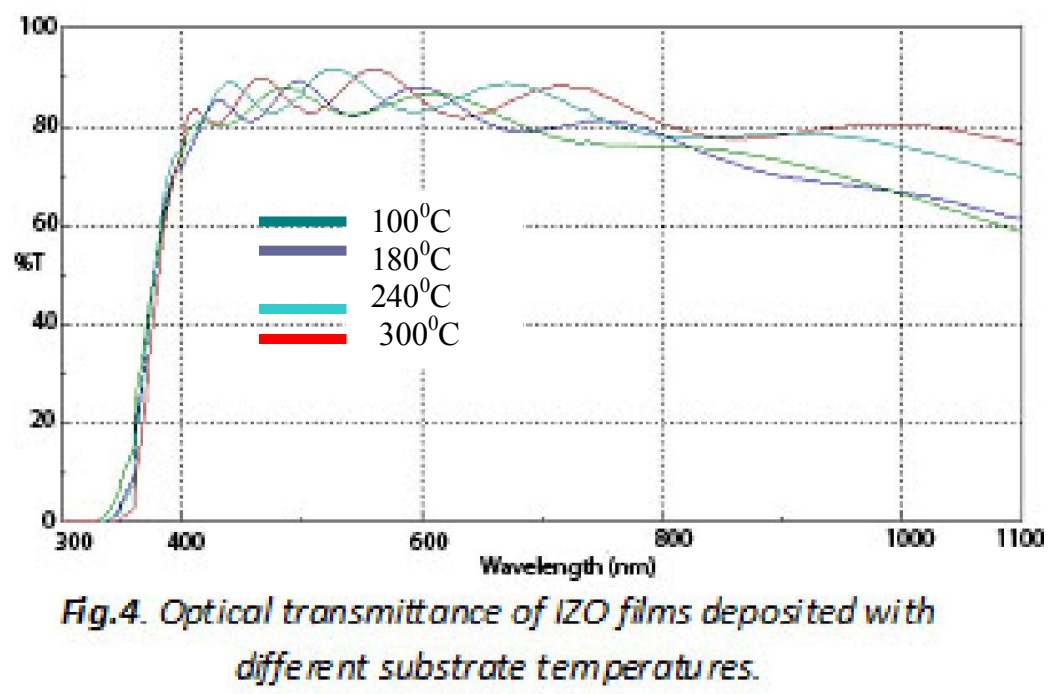

Fig.4 shows that all IZO films have the transparent highly about $90 \%$ in the visible spectra. However, in the near infrared, the transparent of IZO films trend to decrease due to the high carrier concentration.[4] 
$\mathrm{T}_{\mathrm{S}}: 200^{\circ} \mathrm{C}$

$\mathrm{R}_{\text {RMS }}: 8.29 \mathrm{~nm}$

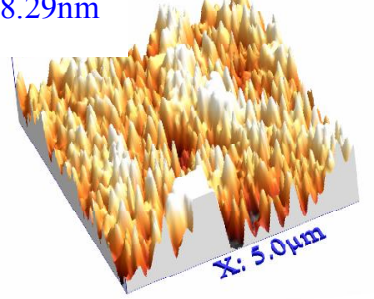

$\mathrm{T}_{\mathrm{S}}: 240^{\circ} \mathrm{C}$

$\mathrm{R}_{\text {RMS }}: 5.47 \mathrm{~nm}$

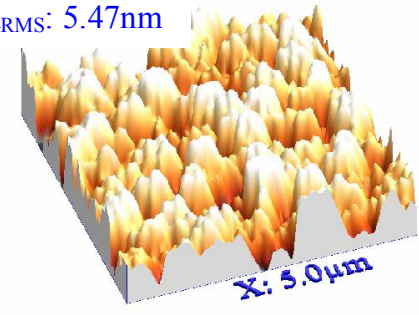

$220^{\circ} \mathrm{C}$

is: $8.67 \mathrm{~nm}$

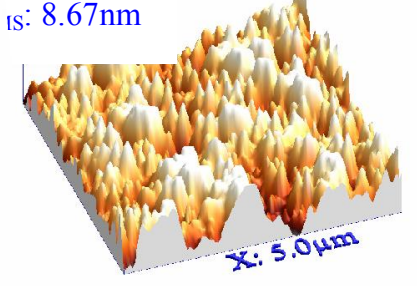

$\mathrm{T}_{\mathrm{S}}: 260^{\circ} \mathrm{C}$

$\mathrm{R}_{\text {RMS: }}: 17.53 \mathrm{~nm}$

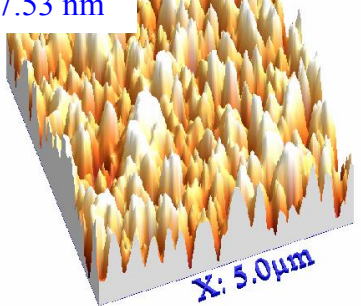

Fig.5 AFM images on IZO films with different substrate temperatures.

Fig.5 shows that the lowest root mean square $\left(\mathrm{R}_{\mathrm{RMS}}\right)$ of surface roughness was 5.47 $\mathrm{nm}$. This value corresponds with the IZO film at the substrate temperature $240^{\circ} \mathrm{C}$ and this sample also had minimum resistivity $1.79 \times 10^{-}$ ${ }^{3} \Omega \mathrm{cm}$.[5]

\section{CONCLUSIONS}

From the results of this research, we can conclude that IZO thin films has been sucessfully deposited by magnetron $\mathrm{dc}$ sputtering technique on glass substrate.

- Studying the electrical and optical properties of IZO films with difference of In concentrations in ceramic targets, it has been indicated that the best concentration in target to make best IZO thin films is In $2-3 \mathrm{wt} \%$, with the resistivity at $2.12 \times 10^{-3} \Omega \mathrm{cm}$ and the transparent above $80 \%$ in the visible spectra.

- As the substrate temperature increases, the resistivity of IZO films trends to decrease. At the temperature about $240^{\circ} \mathrm{C}$, the resistivity of films can reach $1.79 \times 10^{-3} \Omega \mathrm{cm}$ and the transparent of films about $85 \%$ in the visible spectra, corresponding with the transparent conducting very well.

\section{Trang 76}




\section{CHÊ TẠO MÀNG DẪN ĐIỆN TRONG SUỐT ZnO:In BẰNG PHƯƠNG PHÁP PHÚN} XẠ MAGNETRON DC

\section{Hồ Văn Bình, Lê Vũ Tuấn Hùng, Lê Quẹo, Phạm Thanh Tuân,} Dương Ái Phương, Lê Văn Hiếu

Trường Đại học Khoa học Tự nhiên, ĐHQG-HCM

TÓM TÄT: Màng ZnO:In đươc chế tạo trên đế thuỷ tinh bằng phuoong phún xạ magnetron dc tù bia gốm $\mathrm{ZnO}: \mathrm{In}$. Các bia gốm $\mathrm{ZnO}$ :In có nồng độ $\mathrm{In}_{2} \mathrm{O}_{3}$ thay đổi tù 1 đến $4 \%$ khối lương. Màng có điện trở suất $1.79 \times 10^{-3} \Omega \mathrm{cm}$ với độ dày màng khoảng $1 \mu \mathrm{m}$ ưng với bia gốm có $2 \% \mathrm{In}_{2} \mathrm{O}_{3}$, nhiệt độ đế khoảng $240^{\circ} \mathrm{C}$. Tất cả các màng ZnO:In đều có độ truyền qua trên $85 \%$ trong vùng ánh sáng khả kiến.

Tù̀ khoá: Màng oxide dẫn điện trong suốt (TCO), Phún xạ magnetron dc, ZnO:In

\section{REFERENCES}

[1]. J.Wienke, A.S.Booij, Thin Solid Films (2007).

[2]. Young Ran Park, Eung Kwon Kim, Donggeun Jung,Tae Seok Park, Young Sung Kim, Applied Surface Science 254 (2008), 2250-2254.

[3]. K.J.Chen, F.Y.Hung, S.J.Chang, Z.S. $\mathrm{Hu}$, Applied Surface Science $\mathbf{2 2 5}$ (2009), 6308-6312.
[4]. D.G. Kim, S.Lee, D.H.Kim G.H. Lee, M. Isshiki, Thin Solid Films 516 (2008), $2045-2049$.

[5]. M.N. Jung, E.S. Lee, T.-I. Jeon, K.S. Gil, J.J. Kim, Y. Murakami, S.H. Lee, S.H. Park, H.J. Lee, T. Yao, H. Makino, J.H. Chang Journal of Alloys and Compounds 481 (2009), 649-653. 